\title{
THE ROLE OF HUMAN, SOCIAL AND CREATIVE CAPITALS IN SOCIO-ECONOMIC DEVELOPMENT
}

\author{
Katarzyna Szara, $\mathrm{PhD}^{1}$; Anna Mazurkiewicz, $\mathrm{PhD}^{2}$
}

Faculty of Economics, University of Rzeszów

\begin{abstract}
Socio-economic development is a process of quantitative and qualitative changes that increase phenomena in the economic, social and cultural areas. Various types of capital, including human and social capitals, support this development. These capitals are often described in literature. Less information on the subject of creative capital derived from the Florida's theory is available in the subject matter literature.

The aim of the paper is to identify the role of human, social and creative capitals in socio-economic development. Against the background of the capitals characteristics, their similarities and differences were pointed out. Human capital is substitutive against social and creative ones. However, these two capitals have a complementary character in relation to human nature. The identified roles of the three capitals described in the comparative dimension in the aspect of a commune, a region and a country development are an original contribution to the paper.
\end{abstract}

Keywords: human capital, social capital, creative capital, development JEL codes: O1, O15, R10

\section{INTRODUCTION}

Socio-economic development is a process of quantitative and qualitative changes that increase phenomena in the economic, social and cultural areas. These changes take place in terms of time and space and are determined by various factors. This development is characterized at the level of a country, a region and a municipality.

A man occupies an important place in social and economic development. It is described in numerous items of literature. An analysis of human capital can be considered from the perspective of business entities that run their business in a given region and as a resource located in this area. A place - a location is the distinction of this capital. The place is also associated with the social capital distinguished due to the specificity of a group, a community. This factor also determines the 'occurrence, attraction' of the creative capital. So-called creative class is said to be a representatives of this capital in literature. This group is distinguished according to the criterion of a profession. It uses creativity, which according to the author of the creative class theory, is the driving force of economic growth and dominates in society (Florida, 2010).

The aim of this paper is to identify the role of human, social and creative capitals in socio-economic development. The specific objective is to promote the creative capital as the least recognized capital in the subject matter literature. It was taken due to an

${ }^{1}$ Correspoding author: al. Rejtana 16c, 35-001 Rzeszów, Poland, 33ksz@wp.pl, +4860 9987770

${ }^{2}$ Correspoding author: al. Rejtana 16c, 35-001 Rzeszów, Poland, annam@ur.edu.pl, +4817 8721677 
interest of organizations and institutions in the creativity that formed its foundation. Another necessary condition was the promotion of development in the literature based on this capital mainly in urban areas (Landry, 1995). Few publications, however, indicate its importance in rural areas.

\section{THEORETICAL BACKGROUND, MATERIALS AND METHODS}

The article is of theoretical character. In pursuing the adopted purpose of the paper, the subject matter literature in the field of economics and management sciences was subject to a critical analysis. The deductive and reduction methods were applied.

Due to a wide range of research issues related to an identification of differences between concepts of capital, the considerations were limited to theoretical comparisons covering the indicated capitals in selected aspects. The analysis was carried out in the context of the region development. The subject matter is extremely complex due to its interdisciplinary character. However, it allows making a comparison of knowledge from different disciplines of science that discover new research fields, and which are the subject of interest for further, more detailed research.

The selected, subjectively presented roles of the three capitals are the results of the literature analysis. The most common in the literature is a comparison of the capitals: human and social ones. The comparison of the creative capital with them is an original contribution to the theory.

\section{SUBJECT FEATURES OF THE CHARACTERIZED CAPITALS}

Capital is a term that refers to goods that serve to start or continue a business activity. It is one of the means of production in addition to labour, entrepreneurship and land which are needed to start production (Marchewka, 2000).

Human capital is interpreted at the level of an organization, a team, and at the level of an individual. However, an analysis at a more general level is not only a sum of features that characterize the lower level. It is necessary to take into account some fac- tors that merge individuals (both human and organizational ones) (Mazurkiewicz, 2010). Human capital in a country is treated as a 'source of knowledge, skills, health and vital energy contained in a given society/nation' (Schultz, 1961). It favours: innovations of economies, their ability to absorb new scientific, technical, organizational and other solutions, promotion of modern consumption and quality of life practices, shaping of modern technical and organizational, IT and social infrastructure, etc.

On the other hand, social capital means some characteristics of groups, collectivity, structures, organizations, so-called 'interpersonal space' or 'social field'. It is created and transmitted by social mechanisms (Herbst, 2007). Individual social capital results from social, ethnic origin, or a tied-up network of connections. In a collective context it means that a specific social group is its 'carrier'. Its elements are acquired and inculcated during socialization and adaptation of an individual to live in a group (Herbst, 2007).

Social capital contains several separate elements. Its two basic components are its own influences, connections and knowledge of individuals who, under some circumstances, may be treated as a kind of contribution to already existing or just forming social networks, or even as a simple 'trade offer' with its fixed price and clearly defined sales conditions, intra-group loyalty and solidarity and intra-group trust (Ziółkowski, 2012).

The concept of creative capital is related to Florida's theory. He defines it by presenting the assumptions of the creative class. The author claims that this class draws its identity from the role of creativity suppliers. Assuming that creativity is the driving force of economic growth, this class has become dominant in society (Florida, 2010). It is proposed to accept that the creative class is a narrowly defined creative capital, while the broader definition recognizes creative capital as a source appropriate for people who cooperate and function in new conditions using their creativity (Szara, 2017). Innovations, patents and improvements are the effects of people's creative work. These creative actions result from the self-consciousness of a person. It may happen that they are activated under the influence of relationships with other people. Then they will appear at the level of social capital 
and interpersonal relationships. Although Florida's considerations suggest that social capital should be replaced by the concept of creative capital, this is a debatable statement. It should be agreed that strong social ties 'weaken' or even 'kill' creativity. Hence, one should not deny the individuality and diversity resulting from the essence of creativity. It is a man who individually starts their creative abilities, searches for new solutions guided by their knowledge.

Both human and social capitals are important factors for socio-economic development. All three analysed types of capitals are difficult to define. This results from their ambiguity. They differ in their characteristics due to the number of units they are referred to. However, all three capitals are closely related.
Human capital determines the existence of social and creative capital, while the social one can contribute to the enrichment or weakening of creative capital. Creative capital is inseparable from human capital, but not always with the social one.

When comparing human and creative capital, one can point to the following similarities: definition multidimensionality, an ability to 'multiply', fathering a human being to a person, a possibility to generate benefits, freedom of location, common effects, problem solving, a measurement difficulty, depreciation, an ability to make choices. However, they differ in: the perception of values, the mechanisms of action, the degree of an impact on economy, a lack of accumulation (Table 1).

Table 1. Similarities and differences between the human, social and creative capitals

\begin{tabular}{|c|c|c|}
\hline Specification & Similarities & Differences \\
\hline \multirow{11}{*}{$\begin{array}{l}\text { Human capital / } \\
\text { /Creative capital }\end{array}$} & Multidimensionality (heterogeneity) definition & Differences in the perception of value \\
\hline & An ability to 'multiply' & Different mechanisms of action \\
\hline & An ability to 'achieve' for every human being & The advantage of the creativity features \\
\hline & Opportunities to generate benefits & Different degree of impact \\
\hline & Freedom of placement & Different degree of use \\
\hline & Common effects & You cannot accumulate \\
\hline & $\begin{array}{l}\text { An ability to solve problems } \\
\text { Indissolubility }\end{array}$ & Differences in the area of education \\
\hline & Difficulty of measurement & - \\
\hline & Depreciation & - \\
\hline & Uncertainty of effects & - \\
\hline & An ability of selection & - \\
\hline \multirow{8}{*}{$\begin{array}{l}\text { Social capital / } \\
\text { /Creative capital }\end{array}$} & Multidimensionality (heterogeneity) definition & High mobility of creative capital \\
\hline & An ability to 'multiply' & Different degree of use \\
\hline & Reliance on cooperation & Individualism \\
\hline & An improvement of the quality of relationships & Autotelic values \\
\hline & Creating values depending on one's needs & Social capital can quickly 'destroy' \\
\hline & Independence of people's creativity & Differences in the assessment of effects \\
\hline & The level of intimacy - creative & Intensity level (spatial, organizational, emotional) \\
\hline & Transformation & Creating structures \\
\hline
\end{tabular}

Source: Szara (2015). 
In the case of a comparison of the creative and social capital some common features are identified, such as: definition multidimensionality, an ability to 'multiply', relying on cooperation, independence of people 'creating' these capitals, transformability. In turn, the differences include: high mobility of the creative capital, different degree of exploitation, individualism, autotelic values, differences in an assessment of effects, a level of closeness, creation of structures (Szara, 2015).

\section{HUMAN, SOCIAL AND CREATIVE CAPITAL IN THE PROCESS OF REGIONAL DEVELOPMENT}

Pointing at different socio-economic potential of a specific space, the need to include not only human capital, but also social one in a development assessment is emphasized. This is a prerequisite for synergistic effects that can help overcome the barriers to build creative Europe (Wosiek, 2016). The proposal to include creative capital into the assessment results from the promotion of the importance of creativity in economy (Boschma and Fritsch, 2009).

All three types of capitals are considered to be important determinants of economic development (Czapliński, 2009; Florida, 2010; Mazurkiewicz, 2010; Marszałek-Kawa and Pająk eds., 2015). They are economic in nature and are connected with a human, but they require investments. Multidimensionality is also their common feature, but they are related to people's behaviour. In the case of social and creative capital, behaviours based on honesty, trust and creativity are identified in detail.

The identified roles signify the participation and significance of capital in socio-economic development. They are based on the tasks set to be fulfilled on the basis of the literature. The selection of 'roles' and an assessment of their impact strength is subjective, which served to compare the importance of creative capital in development to other capitals (Table 1). The subjective nature of the analysis resulted from the difficulty of comparing the research of other authors mainly in relation to creative capital, which was an element of criticism of this capital in the literature. The results of the works of other authors are often not comparable due to the lack of analogical data adopted from an assessment of creative capital (Peck, 2005; Boschma and Fritsch, 2009) - Table 2.

\section{RESULTS AND DISCUSSION}

The reference to the role of the presented capital is connected with an indication of selected areas of influence. They allow determining the relationships

Table 2. The role of individual capitals in the context of socio-economic development

\begin{tabular}{|l|c|c|c|c|}
\hline Role & $\begin{array}{c}\text { Human } \\
\text { capital }\end{array}$ & $\begin{array}{c}\text { Social } \\
\text { capital }\end{array}$ & $\begin{array}{c}\text { Creative } \\
\text { capital }\end{array}$ & Changes direction \\
\hline Development determinants & +++ & ++ & + & It sets the direction for development \\
\hline Innovative & +++ & + & ++ & New solutions \\
\hline Knowledge-creative & +++ & + & ++ & New knowledge \\
\hline Relational & ++ & +++ & + & $\begin{array}{c}\text { The created relationships strengthen cooperation } \\
\text { or suppress it }\end{array}$ \\
\hline An ability to replace & +++ & ++ & ++ & Substitutability or complementarity \\
\hline Culture-creative & ++ & + & ++ & Creation of cultural works \\
\hline Standards-setting & +++ & +++ & + & Creation of new rules, standards \\
\hline Economic & +++ & + & + & Income generation \\
\hline
\end{tabular}

$(+)$ activity of capital influence on socio-economic development.

Source: author's own research. 
between them as complementary ones. Each of the capital is in its essence important for economic development and should be taken into account during an implementation of regional policy tasks, which is emphasized, for instance by Kotarski (2013). The role of the distinguished capitals in socio-economic development is also based on the relationship of the use of common practices presented in the research, e.g. by Lee, Wong and Chong (2005). Each of the capitals analysed separately affects the quantitative and qualitative changes in the economic (World Economic Forum, 2013), cultural (European Commission, 2018) and social areas ${ }^{3}$. Human and creative capitals generate an increase in production revenues. They influence on the development of new phenomena mainly in the creation of innovations (Miguélez et al., 2008), building new enterprises or knowledge (Alexopoulos and Monks, 2004). Social capital affects changes in the abovementioned areas, but mainly in the one related to building interpersonal relationships that can contribute to benefits both in time and in space (Zak and Knack, 2001; Parts, 2013). The role of human and social capitals in the process of economic growth and region development is indicated by the results of numerous empirical studies (Czapliński, 2009; Kancelaria Prezesa Rady Ministrów, 2009). Kaasa and Parte (2008). By contrast, the role of creative capital in development was identified at the lowest impact level in comparison to the other two capitals. Florida (2010) research showed only the correlation dependence between development and the criteria of talent, technology and tolerance that describe this capital. The comparison made in this paper is one of the few attempts to eliminate the critique of creative capital in world literature concerning, among others, similarities to human capital (Montgomery, 2005) and relationships which are the characteristic features of social capital (Peck, 2005; Boschma and Fritsch, 2009). An attempt to indicate the strength of the influence of individual capitals on the development in the role model is a proposal to diversify an impact of these capitals.
The literature also comments on the lack of interest in the subject of creative capital in rural areas (Thulemark and Hauge, 2014). Its role is emphasized for urban development (Markusen, 2006; Stryjakiewicz and Stachowiak, 2010).

With reference to the above commentary the distinguished roles of creative capital, in addition to an implementation of the specific objective, include also information on the potential to use it in rural areas (Szara, 2017). Also, the European Commission points at the usefulness of activities based on creative capital in the creative sector in rural areas (European Network for Rural Development, 2009; European Commission, 2018).

The roles performed by individual capitals are different, and the differences between them are poorly identifiable. An attempt to determine these roles is the first stage to a more detailed and insightful comparative characteristics.

In the future it may include a quantitative and qualitative assessment evaluating the strength of an impact of a given capital within the designated roles; determining the benefits of the presence of creative capital on various economic and social levels and empirical and statistical verification of the relationship between capitals.

\section{CONCLUSIONS}

In this paper the role of capitals: human, social and creative ones were discussed. Creative capital evolved as a result of human activities that had economic consequences. It is a derivative of human capital and can be identified as a manifestation of an interaction of human and social capital.

All three capitals are perceived as a factor of socio-economic development. Regardless of the classification and characteristics criterion, they allow using human abilities in a better way. The benefits are obtained both in the social and economic areas. In the case of creative capital this is connected with the economic function and connected with it social and cultural preferences of people, consumer habits and

${ }^{3}$ European Social Studies Data website http:// nesstar.ess.nsd.uib.no. 
social identity, which results from the nature of creativity - its individuality and diversity. In the paper the role of the capitals in the comparative system were identified. The attention was paid to the comparison in the area of innovations, relations, culture-creating and economic.

In the comparison the strongest impact was attributed to human capital. This is mainly due to the fact that the other two capitals are its derivative. Creative capital is of lesser importance for the development, probably due to the low degree of recognition of its importance in the literature. The authors proposed the conclusions that the roles these capitals play should have a complementary character, which is a new element of knowledge in the case of creative capital. The distinction of creative capital does not mean replacing human or social capitals. It allows a coherent symbiosis of capitals, the search for common paths of development through creativity. These capitals indicate intangible assets which are the basis to identify and improve key human competences.

In the summary of the analysis, one should point to the limitations related to the research tasks. They are related to: an ambiguity of the analysed concepts which results in the penetration of economic content connected with human capital, sociological one that refers to social capital, and creative capital analysed in the course of economic research. Therefore, there is a need to develop a tool for further research and to adopt additional, detailed methodological assumptions so that in the future the obtained results were objective in nature. The lack of comparability of the research results of other authors resulting precisely from differences in the accepted research methodology is often a difficulty in the analysis of creative capital. In comparison of the role of capital the charge of 'copying' solutions regarding human capital in relation to creative capital may be a limitation. However, despite the research limitations, the comparison and differentiation of the roles of the presented capital is important as it allowed identifying many new research questions that need to be answered.

\section{REFERENCES}

1. Alexopoulos, A., Monks, K. (2004). A Social Capital Perspective on the Role of Human Resource Practices in Intra-Organisational Knowledge Sharing. LINK Working Paper WP 04-04. The Learning, Innovation and Knowledge Research Centre, DCU Business School, Dublin City University, Dublin.

2. Boschma, R.A., Fritsch, M. (2009). Creative Class and Regional Growth: Empirical Evidence from Seven European Countries. Economic Geography, 85, pp. 391-423.

3. Czapiński, J. (2009). Kapitał społeczny [Social capital]. In: Czapiński., J., Panek, T. (eds.), Diagnoza społeczna 2009. Warunki i jakość życia Polaków [Social Diagnosis 2009. The conditions and quality of the Poles' lives]. Rada Monitoringu Społecznego, Warszawa, p. 276.

4. European Commission (2018). Communication from the Commission to the European Parliament, the Council of the European Economic and Social Committee and the Committee of the Regions. The new European program for culture. $\operatorname{COM}(2018) 267$ final of 22.5.2018

5. European Network for Rural Development (2009). Re-imaging rural business opportunities. EU Rural Review, 24.

6. Florida, R. (2010). Narodziny klasy kreatywnej [The Rise of the Creative Class]. Narodowe Centrum Kultury, Warszawa.

7. Herbst, M. (ed.) (2007). Kapitał ludzki i kapitał społeczny a rozwój regionalny [Human capital and social capital versus regional development]. Scholar, Warszawa.

8. Kaasa, A., Parts, E. (2008). Human Capital and Social Capital as Interacting Factors of Economic Development: Evidence from Europe. Working Paper IAREG WP2/04. University of Tartu, Tartu.

9. Kancelaria Prezesa Rady Ministrów (2009). Polska 2030. Wyzwania rozwojowe [Poland 2030. Development challenges]. Warszawa.

10. Kotarski, H. (2013). Kapitał ludzki i kapitał społeczny a rozwój województwa podkarpackiego [Human capital and social capital and the development of the Podkarpackie Voivodeship]. Wydawnictwo Uniwersytetu Rzeszowskiego, Rzeszów.

11. Landry, Ch., Bianchini, F. (1995). The creative city. Demos / Comedia, New York.

12. Lee, S.H., Wong, P.K., Chong, Ch.L. (2005). Human and Social Capital Explanations for R\&D Outcomes. IEEE Transactions on Engineering Management, 52 (1), pp. 59-67. 
13. Marchewka, M. (2000). Główne nurty w teorii kapitału [Main trends in the theory of capital]. Ruch Prawniczy, Ekonomiczny i Socjologiczny, 57 (3), pp. 106-107.

14. Markusen, A. (2006). Urban development and the politics of the creative class: Evidence from the study of artists. Environment and Planning A, 38 (1), pp. 1921-1940 .

15. Marszałek-Kawa, J., Pająk, K. (eds.) (2015). Europejska przestrzeń gospodarcza szansą dla rozwoju regionalizmu w Polsce [The European economic space as an opportunity for the development of regionalism in Poland]. Wydawnictwo A. Marszałek, Torun.

16. Mazurkiewicz, A. (2010). Kapitał ludzki w procesie kształtowania sprawności organizacji [Human capital in the process of shaping the organization's efficiency]. Wydawnictwo Uniwersytetu Rzeszowskiego, Rzeszów.

17. Miguélez, E., Moreno, R., Artís, M. (2008). Does Social and Human Capital Reinforce Each Other in the Creation of Knowledge? Evidence from Spanish Regions. Working Papers 13. Research Institute of Applied Economics, Universidad de Barcelona, Barcelona.

18. Montgomery, J. (2005). Beware 'the Creative Class'. Creativity and Wealth Creation Revisited. Local Economy, 20 (4), pp. 337-343.

19. Parts, E. (2013). The dynamics and determinants of social capital in the European Union and Neighbouring Countries. Discussions on Estonian economic policy: Theory and practice of economic policy in the European Union. doi:10.2139/ ssrn.2336016

20. Peck, J. (2005). Struggling with the creative class. International Journal of Urban and Regional Research, 29 (4), pp. 740-770.

21. Schultz, T.W. (1961). Investment in Human Capital. American Economic Review, 5, pp. 1-17.

22. Stryjakiewicz, T., Stachowiak, K. (2010). Sektor kreatywny w poznańskim obszarze metropolitalnym. Uwarunkowania, poziom i dynamika rozwoju sektora kreatywnego w poznańskim obszarze metropolitalnym [The creative sector in the Poznań metropolitan area.
Conditions, level and dynamics of the creative sector development in the Poznań metropolitan area]. Vol. 1. Bogucki Wydawnictwo Naukowe, Poznań.

23. Szara, K. (2015). Kapitał ludzki, społeczny, kreatywny w rozwoju społeczno-gospodarczym gmin [Human, social and creative capital in socio-economic development of municipalities]. In: Sobczak, E. (ed.) Zarządzanie zrównoważonym rozwojem jednostek samorządu terytorialnego [Management of sustainable development of local government units]. Oficyna Wydawnicza Politechniki Warszawskiej, Warszawa, pp. 78-94.

24. Szara, K. (2017). Uwarunkowania i możliwości aktywizacji kapitału kreatywnego jako determinanty rozwoju lokalnego na przykładzie gmin województwa podkarpackiego [Conditions and opportunities for activating creative capital development, as determinants of local development, based on an example of municipalities in the Podkarpackie Region]. Wydawnictwo Uniwersytetu Rzeszowskiego, Rzeszów.

25. Thulemark, M., Hauge, A. (2014). Creativity in the recreational industry. Re-conceptualization of the Creative Class theory in a tourism-dominated rural area. Scandinavian Journal of Public Administration, 18 (1), pp. 87-105.

26. World Economic Forum (2013). The Human Capital Report. World Economic Forum, Geneva.

27. Wosiek, M. (2016). Komplementarna rola kapitału ludzkiego oraz społecznego $\mathrm{w}$ inteligentnym rozwoju gospodarczym [Complementary role of human and social capital in intelligent economic development]. Studia Ekonomiczne. Zeszyty Naukowe Uniwersytetu Ekonomicznego w Katowicach, 276, pp. 58-71.

28. Zak, P.J., Knack, S. (2001). Trust and growth. The Economic Journal, 111, pp. 311-314.

29. Ziółkowski, M. (2012). Kapitał społeczny, kulturowy i materialny i ich wzajemne konwersje we współczesnym społeczeństwie polskim [Social, cultural and material capital and their mutual conversions in contemporary Polish society]. Studia Edukacyjne, 22, pp. 7-27. 